\title{
The status and conservation of the Chacoan peccary in Paraguay
}

\author{
Andrew B. Taber
}

The Chacoan peccary Catagonus wagneri is endemic to the dry thorn forest of the Gran Chaco of Paraguay, Argentina and Bolivia. Since its discovery by scientists in the 1970s its population has declined due to overhunting, habitat destruction, and possibly disease. As of 1989 about 5000 individuals are estimated to survive in the Paraguayan Chaco. Small dispersed populations still exist in Argentina and Bolivia, but more information is needed on the status of this species in those two countries. In Paraguay, Chacoan peccaries have almost disappeared from the two national parks within their range and the only significant population exists in an area where there are no reserves. The survival of this species depends on enforcing regulations against hunting both within and outside the national parks, translocating animals to the parks, establishing a system of reserves on private land in critical areas, training of Paraguayan wildlife professionals, and environmental education.

\section{Introduction}

In 1975 the scientific community was surprised by the discovery of the Chacoan peccary Catagonus wagneri in the dry thorn forest of the Paraguayan Chaco (Wetzel et al., 1975). This species, thought to have gone extinct in the Pleistocene, was subsequently reported as also occurring in the Chaco of Argentina and Bolivia (Olrog et al., 1976; Eisentraut, 1986). Field workers found that taguá, as the Chacoan peccary is known in Paraguay, were common in the mid-1970s (Mayer and Brandt, 1982; Sowls, 1984). They also reported that hunting pressures and habitat destruction rates were high, and feared that the taguá might disappear within two decades of its discovery (Wetzel, 1981). Today its population has plummeted (Table 1) and it is listed on Appendix 1 of the Convention on International Trade in Endangered Species of Wild Fauna and Flora (CITES) as well as considered Vulnerable by the International Union for the Conservation of Nature (IUCN).

The Gran Chaco (Figure 1), the area to which the tagua is restricted, has one of the highest diversities of large and medium-sized mammals in the Neotropics (see Redford,
Taber and Simonetti, 1990), including both collared peccaries Tayassu tajacu and white-lipped peccaries T. pecari. However, the Chaco's fauna remains poorly studied and the recent discovery of the taguá shows how little attention zoologists have paid to this region (but see Bucher, 1980; Myers, 1982). In 1987 Wildlife Conservation International (WCI) began a collaborative project with the

Table 1. The decline of the Chacoan peccary in the western Paraguayan Chaco as illustrated by the number of taguá seen in this region over varying periods between 1976 and 1987. Data from 1976 to 1981 collected near $\mathrm{km} 580$ of the Trans-Chaco highway (Sowls, 1984). Data for 1987 collected between $\mathrm{km} 580$ and $\mathrm{km} 684$ on the Trans-Chaco highway. Table adapted from Sowls (1984)

\begin{tabular}{lccc}
\hline Year & $\begin{array}{l}\text { Observation } \\
\text { time (days) }\end{array}$ & $\begin{array}{l}\text { No. of } \\
\text { herds seen }\end{array}$ & $\begin{array}{l}\text { No. of } \\
\text { individuals }\end{array}$ \\
\hline 1976 & 19 & 18 & 72 \\
1977 & 21 & 4 & 22 \\
1979 & 13 & 2 & 10 \\
1981 & 19 & 2 & 6 \\
$1988^{*}$ & 10 & 0 & 0 \\
\hline
\end{tabular}

* After 10 days of looking for signs and questioning local people it became apparent that the species had all but disappeared from the region. 


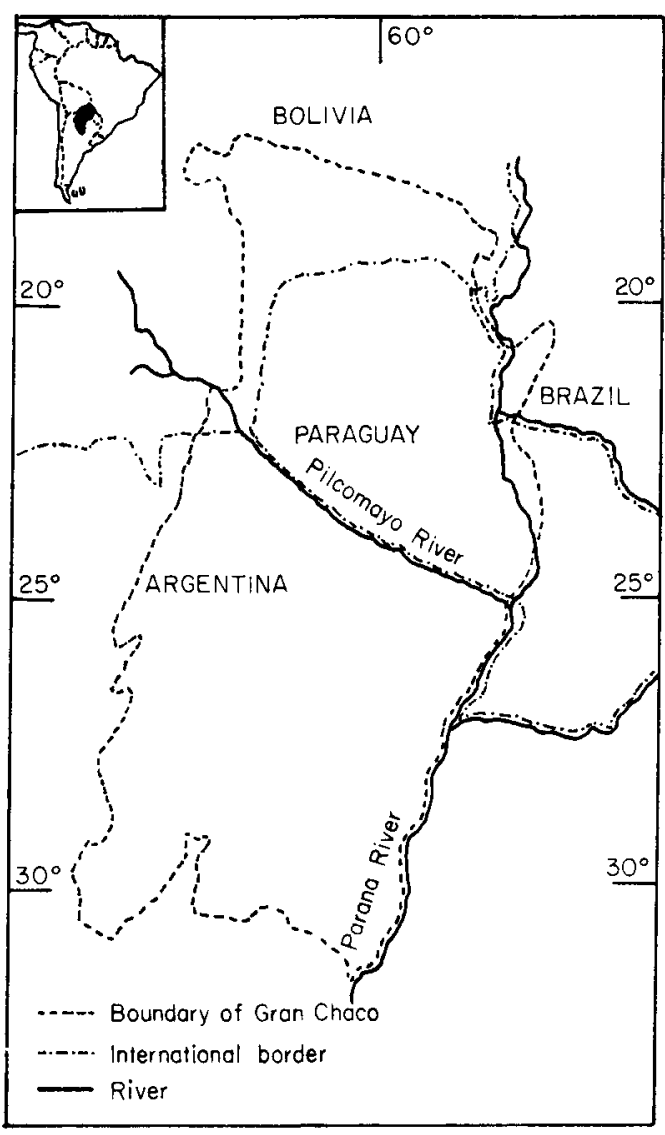

Figure 1. Map of the Gran Chaco. Adapted from Morello and Hortt (1985).
Paraguayan Ministry of Agriculture and Livestock, and the Pigs and Peccaries Specialist Group of the IUCN, to study the distribution, status and ecology of the taguá with the goal of determining how to ensure its survival in the wild. It was hoped that efforts to conserve this species would result in protecting an ecologically viable portion of dry Chaco habitat with all its fauna and flora. An ecological field study in which four taguá were radio-tracked for periods of up to 18 months has now been completed (Taber, unpubl. data). Here, I report on the results of a status survey of the taguá in Paraguay, provide an estimate of its current population size, discuss causes for its decline, and outline a conservation action plan for its protection.

\section{Methods}

From 1987 to 1989 I travelled over much of the Paraguayan dry Chaco collecting information on the distribution and status of Chacoan peccaries (Figure 2). The survey was complicated by the region's size (c. 200,000 sq km), the lack of roads, and the denseness of the thorn bush. Because of the species's scarcity, direct observation was impossible and to obtain information I had to rely greatly on interviews of local peoples: Mennonites, Amerindians, campesinos,

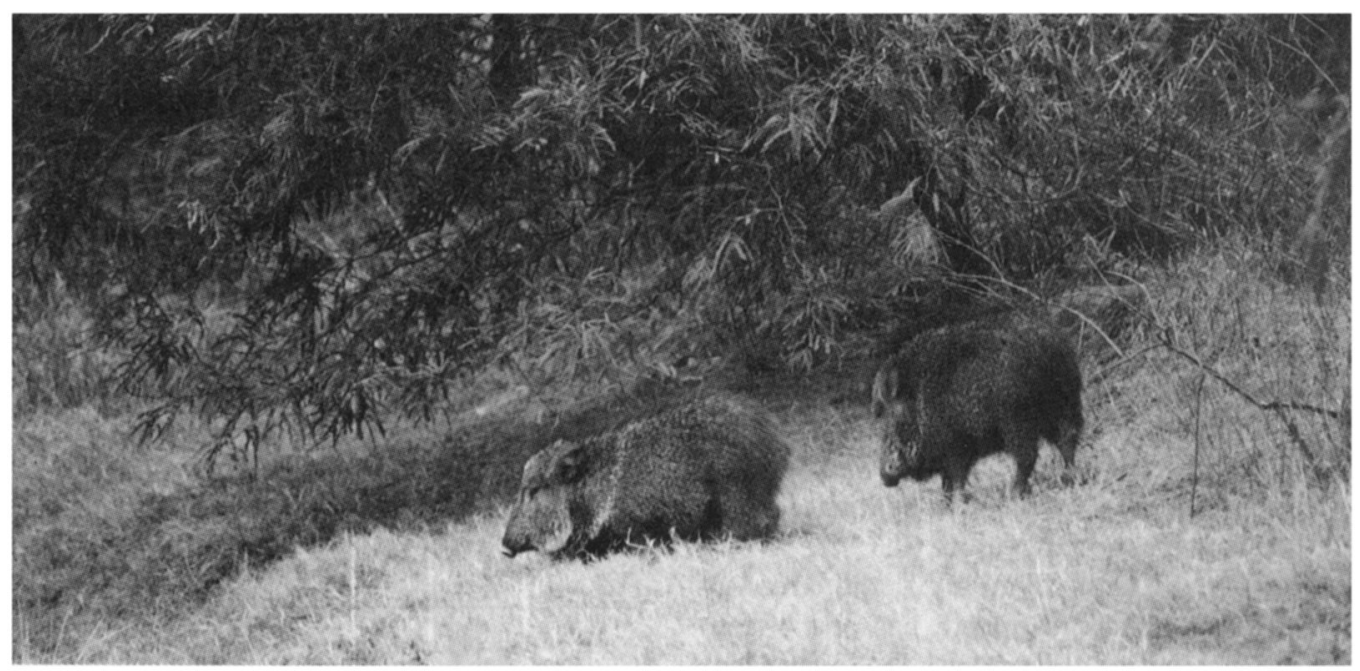

Chacoan peccary Catagonus wagneri (A. Taber). 


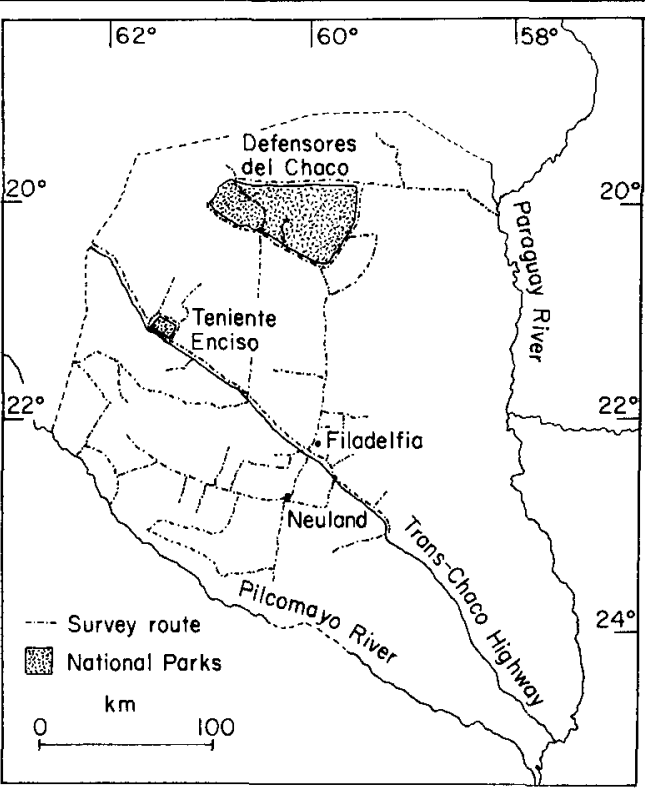

Figure 2. Map showing survey routes covered by the author in the Paraguayan Chaco between 1987 and 1989. Also shown are the locations of Defensores del Chaco and Teniente Enciso National Parks.

ranch owners, missionaries and soldiers. Interviews were conducted when the respondent was able to identify taguá from drawings of all three species of peccaries and accurately describe known aspects of its natural history. A total of 109 persons were interviewed from all parts of the taguá's range in Paraguay. Respondents were questioned whether in their immediate area the species was currently (i) extremely scarce or gone, (ii) rare, (iii) regularly encountered, or (iv) abundant. In addition, I checked the bush around hunters' camps for taguá skulls and examined jaguar Panthera onca and puma Felis concolor scats for peccary hair.

\section{Results}

Taguá were sighted only four times and tracks found seven times during survey trips (Figure 2). Also, 12 skulls or skull fragments were collected from hunting camps and human settlements (specimens deposited in the National Museum of Natural History, San Lorenzo, Paraguay). Of the 109 people interviewed, 59

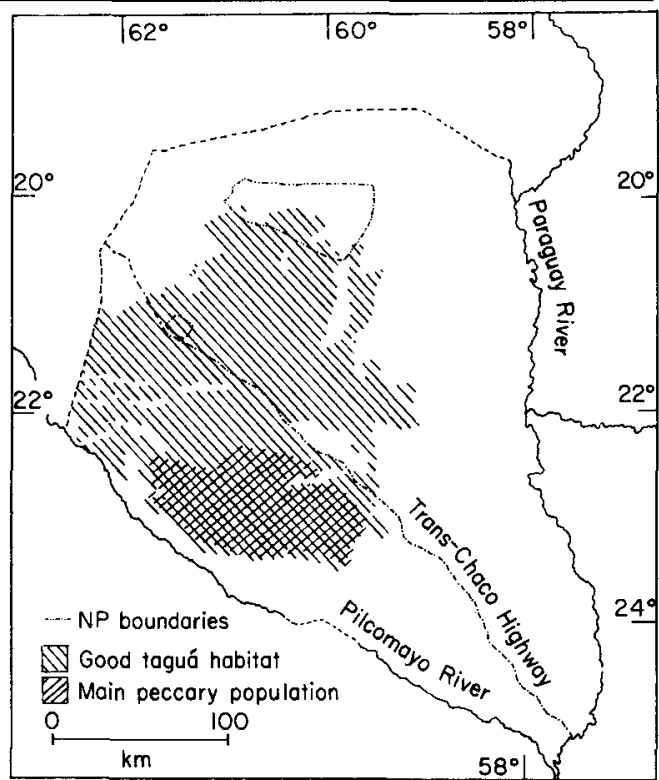

Figure 3. Map showing the distribution of dry thorn forest habitat in the Paraguayan Chaco (modified from Gorostiaga, 1984). Also shown is the portion of this habitat that is still occupied by a significant taguá population.

(54 per cent) reported the species to have completely or almost completely disappeared from their area, 48 (44 per cent) reported the species as rare, and 2 ( 2 per cent) reported the species as regularly encountered. None of the respondents stated that taguá were abundant. The few sightings of taguá, and the interview results, show unequivocally that the population of this species has crashed since its discovery in the mid 1970s (Table 1).

The interview results further reveal that taguá have not declined evenly throughout their range. Data from the literature show that historically taguá were distributed throughout the dry thorn forest of the Paraguayan Chaco (Wetzel, 1977; Mayer and Brandt, 1982; Sowls, 1984). This habitat has a characteristic vegetation of emergent trees such as Schinopsis lorentzii and Aspidosperma quebracho-blanco, a dense shrub layer including species of Caparis and Acacia; and, at ground level, bromeliads and cacti such as Opuntia spp., Cleistocactus baumanii, and Eriocereus guelichii. The distribution of this habitat in the Paraguayan Chaco is shown in Figure 3; though, depending on local 


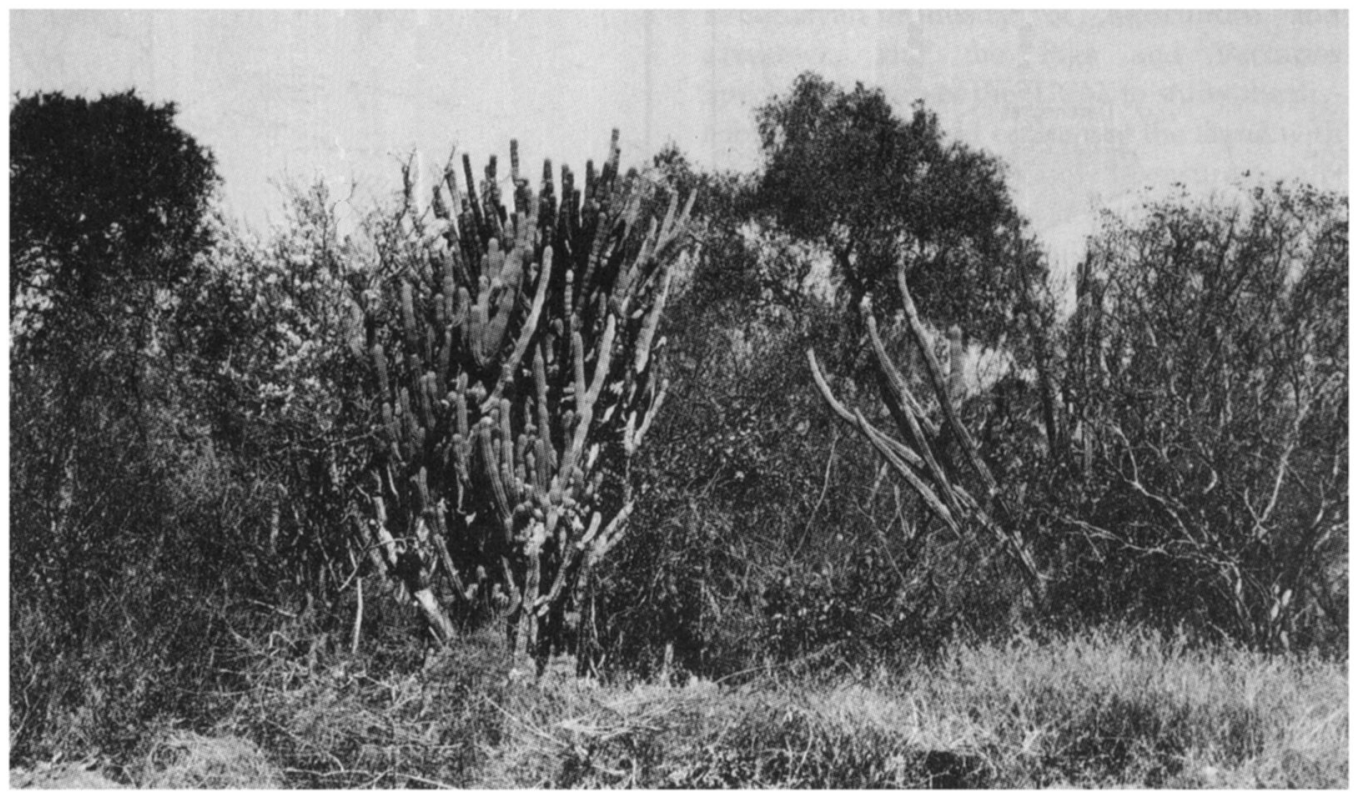

Chaco bush with Cereus coryne (A. Taber).

environmental conditions, isolated islands of appropriate habitat exist elsewhere in the Chaco. Within the taguá's historical range, to the south and west of the Mennonite colony of Neuland (Figure 2), 79 per cent of the people interviewed reported that the taguá was either rare (21:29) or regularly (2:29) encountered and 21 per cent (6:29) reported that the species had disappeared from their area. In contrast, elsewhere in their range 66 per cent $(53: 80)$ of the people interviewed reported the species to be gone or virtually gone from their area and 34 per cent $(27: 80)$ reported the species as rare, and there was no clear pattern to the distribution of the responses. These results show that the taguá now has an extremely fragmented distribution within its historic range; and the only area where a significant population appears to survive, albeit at low density, is to the south and west of the Mennonite colony of Neuland (Figures 2 and 3).

\section{Population estimate for taguá in Paraguay}

The survey results suggest that of approximately $76,500 \mathrm{sq} \mathrm{km}$ of thorn forest habitat only one area in the south-central Chaco, measuring about $12,800 \mathrm{sq} \mathrm{km}$, is still occupied by more than a few remnant taguá groups. Areas were calculated using the count-the-dot method on a vegetation map of the Paraguayan Chaco (Gorostiaga, 1984). A radio-telemetry study of four taguá groups at one site in the Paraguayan Chaco showed that 18 adults occupied an area measuring $42 \mathrm{sq} \mathrm{km}$; giving a density estimate of 0.43 animals per sq $\mathrm{km}$ (Taber, unpubl. data). If this density estimate was representative (and I suspect it was higher than average for the area) this would indicate a taguá population of about 5500 individuals in the south central Paraguayan Chaco. However, even in this area several $100 \mathrm{sq} \mathrm{km}$ have been cleared or modified, and in places the animal has been hunted out, as evidenced by the 21 per cent of the interviewees from this region reporting the taguá as being extremely scarce or gone. Because of these factors, a better estimate of the actual population in this area is probably closer to 4000 adults. Evidence elsewhere in the species's range suggests a vanishingly sparse population of perhaps 1000 individuals. Thus, a reasonable, yet optimistic population estimate for Paraguay would be in the order of 5000 individuals. 


\section{Status of the taguá in Argentina and Bolivia}

During 1989 I verified the presence of tagua in both Argentina and Bolivia. In the Bolivian Chaco, during a brief trip through the department of Tarija, I found a mandible of a taguá probably killed within the past year behind a rancher's house; and was told by campesinos that the animals have always been rare in the region. In a short survey of the Argentine Chaco with Ricardo Ojeda (CRICYT, Mendoza, Argentina) we found taguá to have a fragmented low density distribution in Santiago del Estero, Chaco, and Salta Provinces (Taber and Ojeda, unpubl. data). The future for the species in the Argentine Chaco appears precarious given the high human population density and the ease with which it is taken by hunters (see below).

\section{Causes for the population decline in Paraguay}

I propose the following non-exclusive factors to explain the species's decline:

1. Habitat destruction: information on clearing rates is not available, but there is little fiscal land left in the Chaco and the pace of land clearing is accelerating. Each year hundreds of square kilometres of dry Chaco habitat are cleared to plant buffel grass Cenchrus ciliaris for cattle grazing; or, where conditions are suitable, crops such as cotton, peanuts, sorghum, and increasingly jojoba Simmondsia chinensis. Nevertheless, there are still hundreds of square kilometres of taguá habitat left in the Paraguayan Chaco, so it is unlikely that this species has declined solely because of habitat destruction.

2. Human hunting: hunting of most wild animals, including taguá, has been illegal in Paraguay since 1975 . Unfortunately, the existing regulations are seldom enforced, and hunting has undoubtedly had a major impact on this species. Taguá are easy to shoot as they are diurnal and often come out on roads at midday. They also habitually bunch together as a group and stand their ground as a preda- tor approaches. This is a poor defence against firearms and whole groups of 4-5 adults may be shot out at once. During the late 1970s Sowls $(1984,1985)$ reported that people in the western Chaco virtually lived off Chacoan peccary meat. Unlike collared and whitelipped peccaries, there is little commercial trade in the skin of this species because its hide is thinner than that of the other two and thus not as valuable. In 1988, for example, taguá skins were worth only about $\$$ US0.50 to campesinos while collared and white-lipped peccary skins were worth about $\$$ US 8.00 and \$US5.00, respectively. One argument against the hunting hypothesis is that tagua persist near the Mennonite colonies in the central Chaco and in the Argentine Chaco in areas that have relatively high human population densities, yet have almost disappeared from more isolated areas with presumably much lower hunting pressures.

3. Disease: ten of the people interviewed in the northern and western Paraguayan Chaco reported finding taguá dead or dying from disease between 1979 and 1981 (sources include Amerindians, settlers, and a zoologist: C. J. Dlouhy, Natural History Museum, Geneva). Other peccary species and grey brocket deer Mazama gouazoubira were reported to have also been affected to a lesser extent. There is no direct evidence of what the disease may have been, but both foot-and-mouth disease and bovine rabies were common in the Chaco in the late 1970s (Dr Walter Regehr, Colonia Neuland, Chaco, Paraguay, pers. comm.). It is noteworthy that large numbers of cattle first reached this part of the Chaco during the 1970s; and that tagua survive in parts of the Argentine Chaco that have had cattle and goats, and their associated diseases, for 100 years or more. These two points suggest that a plausible explanation for the crash in the taguá's population in the northern and western Paraguayan Chaco may be that animals there had previous little exposure, and hence little immunity to livestock diseases and as a result suffered a massive die-off.

4. Large carnivores: locals often attributed the collapse of the taguá's population to heavy predation by jaguar and puma. While two of 
my four radio-collared taguá were probably killed by large cats, because this species has survived for millennia despite predation by large carnivores this hypothesis seems implausible. Nevertheless, jaguar and puma could have a detrimental impact on a peccary population reduced for other reasons.

All of the above factors may have had some impact on the species. In the more developed regions of the Chaco overhunting and habitat destruction are undoubtedly responsible for the decline in taguá populations. However, for the northern and western Paraguayan Chaco the disease hypothesis is compelling, although unproven, if only because Ayoreo amerindians living deep in the bush, many kilometres from roads and out of reach of most hunters, report that there are virtually no more taguá. Nevertheless, if disease is a problem, surviving animals must develop some immunity because this species persists in areas where they are continually exposed to livestock diseases; thus, wild populations may be able to recover if given a chance. Regardless of what may have happened in the past, the increasing pace of development in the Paraguayan Chaco, inevitably bringing habitat destruction on a massive scale, is likely to be the demise of this species unless concrete steps are taken.

\section{National parks}

There is little reason to put much hope in national parks preserving the species at present. There are two national parks in Paraguay within the taguá's range: Defensores del Chaco (7800 sq km) and Teniente Enciso (400 $\mathrm{sq} \mathrm{km}$ ). However, populations in both are very low: sightings of taguá in and near the parks are rare occurrences; and my only confirmation of their presence is the finding of Chacoan peccary hair in large felid scats collected in the parks ( 3 of 12 scats from Teniente Enciso, and 1 of 154 scats from Defensores del Chaco). Although Teniente Enciso is clearly good habitat for taguá (Sowls, 1984), interviews of settlers and direct observations suggest that

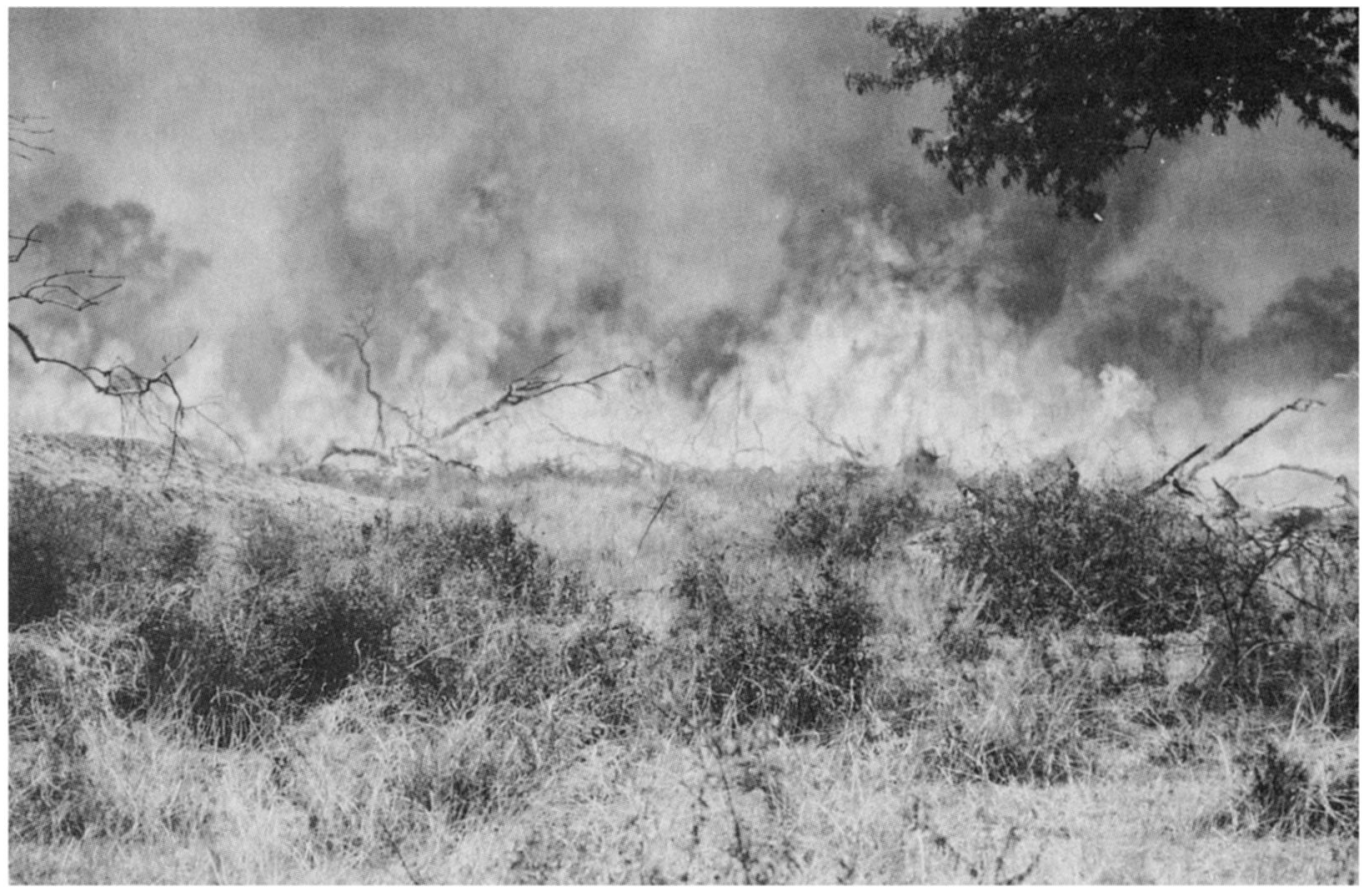

Bush being burned in central Paraguayan Chaco ( $A$. Taber). 


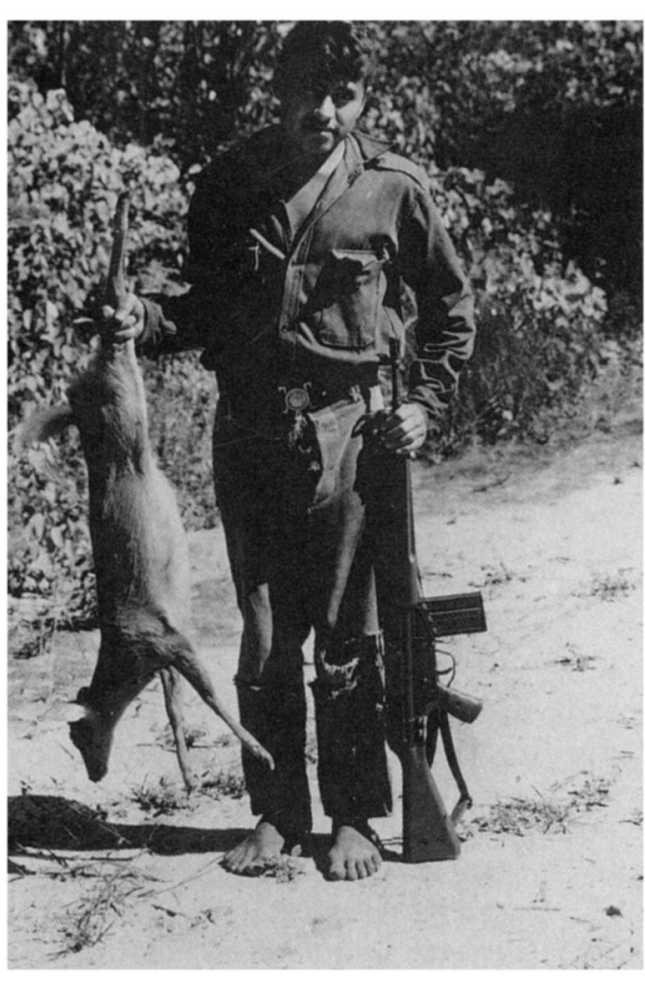

Paraguayan soldier holding a deer just shot in the national park ( $A$. Taber).

much of Defensores del Chaco is suboptimal. Also, the park service has very limited resources: as of March 1990 Defensores del Chaco had only three park rangers and two labourers to patrol it, while Teniente Enciso had only one park ranger and one labourer. Under these conditions the park rangers are unable to control hunting within the parks, and without effective protection there is little likelihood that the remnant taguá populations can recover.

\section{Discussion}

With a declining population of probably fewer than 5000 individuals in Paraguay the longterm prognosis for the species is grim. The south-central Paraguayan Chaco, where the only significant population survives, is subject to heavy development pressures and contains no national parks. In Argentina and Bolivia the future for taguá seems even more precarious: Bolivia does not appear to have much good habitat for the species; and the Argentine dry Chaco is seriously degraded, with little unmodified bush left, an enormous and ecologically disastrous goat population, and a host of impoverished campesinos (Morello and Hortt, 1985; Bucher, 1987). An appraisal of taguá status in these two countries will be made after the completion of surveys during 1990. Nevertheless, the best hope for conserving an ecologically sustainable piece of the dry Chaco with its fauna intact, including its endemic peccary, is probably in Paraguay.

\section{Conservation recommendations}

To conserve this species in the wild it will be necessary to move on a broad front. I have presented a conservation action plan to the Paraguayan Government containing the following elements (Taber, 1990).

1. Improvement of the Paraguayan National Parks system: the park service needs major investments in personnel, training, equipment and infrastructure.

2. Creation of a private reserve system: with the only significant taguá population surviving outside the parks, finding a way to protect these animals is critical. Such a system would provide protection for taguá outside the national parks, and a potential source of animals for translocation to the parks if populations in them do not recover with effective protection. Several problems must be confronted including: will reserves be large enough to maintain viable populations? and, how can land owners be motivated to join and stay within a reserve system?

3. Establishment of an effective hunting ban on the species: the success of this probably depends on legalizing hunting of non-threatened species outside parks and reserves to take the pressure off vulnerable species such as the taguá. The current ban on hunting is clearly ineffective and counterproductive; and only by confronting both wildlife conservation issues and the needs of rural subsistence hunters will Paraguay be able to protect its 


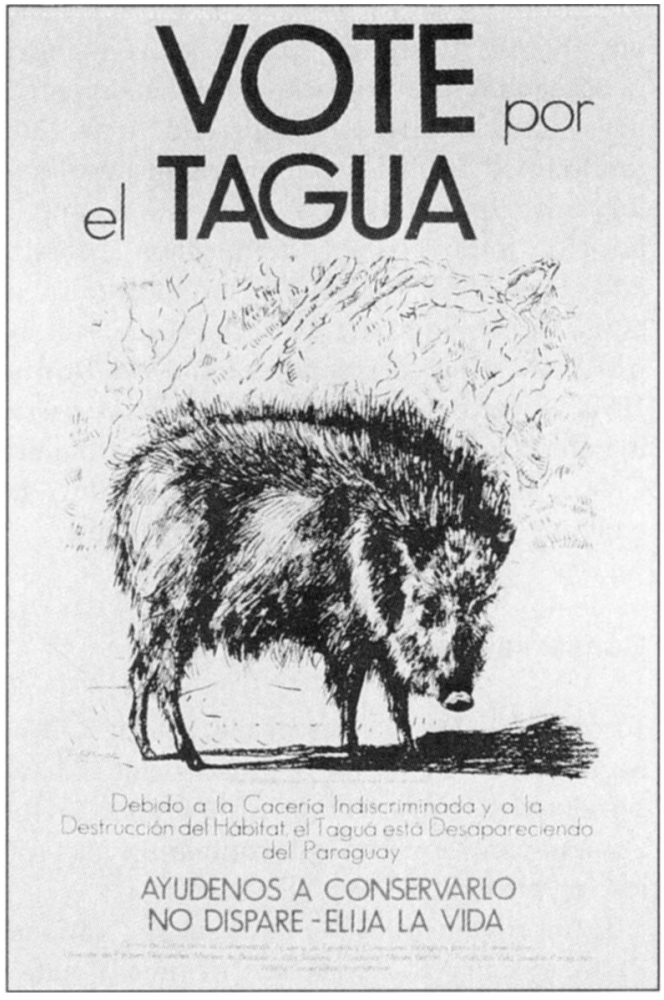

Poster used to convey conservation message to the Paraguayan public (A. Taber).

threatened species. To confront these issues the Paraguayan Government will need to develop a wildlife service capable of monitoring wildlife populations and controlling the harvest.

4. Environmental education: the taguá in Paraguay has tremendous potential as a flagship species around which to stimulate wildlife conservation in the Chaco. Programmes need to be devised to encourage people in the Chaco to use wildlife resources rationally; and must disseminate information on both what species are protected and what species can be harvested (assuming hunting of non-vulnerable species is legalized).

5. Local professional development: there is a desperate need for wildlife biologists in Paraguay if an effective wildlife service is to be developed. In-country conservation biology workshops and grants for students to study for advanced degrees are a high priority.

6. Translocation and captive breeding: the captive breeding project of the San Diego and Lincoln Park Zoos (Byrd et al., 1988) should continue their work with the goals of determining how to breed taguá in captivity, how to reintroduce captive-reared animals into the wild, and how to translocate wild-caught animals from areas being cleared into the national parks.

7. Field research: knowledge of $C$. wagneri and its habitat remains rudimentary. Many aspects of the taguá's ecology need to be studied, particularly if Paraguay is to initiate an effective wildlife management plan for the species.

While the long-term future for taguá does not appear promising, there is still a chance to reverse the situation as long as a significant contiguous population exists. It is now time to test whether the international conservation community, the Paraguayan Government and Paraguayan people have the will to conserve this remarkable animal, with its habitat, in the wild. If action is not taken it is all too possible that this species will have disappeared from the wild by the end of this century.

\section{Acknowledgments}

This study is the result of a collaborative effort between Wildlife Conservation International, the Pigs and Peccaries Specialist Group IUCN/SSC, and the Paraguayan Ministry of Agriculture and Livestock. I gratefully acknowledge the help of many government officials in Paraguay including $O$. Mesa, R. Torres, R. Gauto and C. Acevedo. I also thank N. Neris, F. Colman, R. Diaz, J. C. Rebollo, S. Gonzalez, H. Waldbrunner and W. Friesen for assisting me on survey trips. W. Oliver, G. Schaller and L. Sowls provided much valuable advice for which I am grateful. I offer thanks to K. Redford and D. Ayerza for their comments on drafts of this article. Lastly, I extend my thanks to all the 'chaqueños' who so kindly answered my many questions.

\section{References}

Byrd, M.L., Benirschke, K.B., and Gould, G.C. 1988. Establishment of the first captive group of the Chaco peccary, Catagonus wagneri. Zool. Garten, 58, 265-274.

Bucher, E.H. 1980. Ecología de la fauna Chaqueña. Una revisión. Ecosur, 7, 111-159.

Bucher, E.H. 1987. Herbivory in arid and semi-arid 
regions of Argentina. Revta. Chil. Hist. Natural, 60, 265-273.

Eisentraut, M. 1986. Uber das Vorkommen des Chaco-Pekari, Catagonus wagneri, in Bolivien. Boon. zool Beitr. 37, 43-47.

Gorostiaga, O.L. 1984. Formaciones vegetales del Chaco Paraguayo. Proyecto Desarrollo Regional Integrado del Chaco Paraguayo, Asunción. Serie Información Basica, 2, 1-31.

Mayer, J.J. and Brandt, P.N. 1982. Identity, distribution, and natural history of the peccaries. Tayassuidae. In: Mammalian Biology in South America (eds M. A. Mares and H. H. Genoways), Special Publ. Ser. Pymatuning Lab. Ecology. Univ. Pitt, 6, 433-455.

Morello, J. and Hortt, G. 1985. Changes in the areal extent of arable farming, stock raising and forestry in the South American Chaco. Appl. Geogr. Develop. (Tubingen), 25, 109-127.

Myers, P. 1982. Origins and affinities of the mammal fauna of Paraguay. In: Mammalian Biology in South America (eds M. A. Mares and H. H. Genoways), Special Publ. Ser. Pymatuning Lab. Ecology. Univ. Pitt, 6, 85-93.

Olrog, C.C., Ojeda, R.A. and Barquez, R.M. 1976. Catagonus wagneri (Rusconi) en el noroeste
Argentina (Mammalia Tayassuidae). Neotropica, 22(67), 53-56.

Redford, K.H., Taber, A.B. and Simonetti, J.A. 1990. There is more to biodiversity than the tropical rain forests. Conservation Biology, 4(3), 328-330.

Sowls, L.K. 1984. The Peccaries. University Arizona Press, Tucson.

Sowls, L.K. 1985. Ecology, behavior and status of the Chacoan peccary (Catagonus wagneri) in Paraguay. Nat Geogr. Res. Repts, 21, 457-462.

Taber, A.B. 1990. El Taguá, un Plan de Acción para su Conservación en el Paraguay. Editora Litocolor, Asunción, Paraguay.

Wetzel, R.M. 1977. The Chacoan peccary Catagonus wagneri (Rusconi). Bull. Carneg. Mus. Nat. Hist, 3, $1-36$.

Wetzel, R.M. 1981. The hidden Chacoan peccary. Carneg. Mag, 55(2), 24-32.

Wetzel, R.M., Dubos, R.E., Martin, R.L. and Myers, P. 1975. Catagonus, an 'extinct' peccary, alive in Paraguay. Science, 189, 379-381.

Andrew B. Taber, Wildlife Conservation International, New York Zoological Society, Bronx, New York 10460, USA. 